\title{
Relation between the microstructure and technological properties of porcelain stoneware. A review
}

\author{
M. Romero $\bowtie$, J. M. Pérez \\ Eduardo Torroja Institute for Construction Sciences, IETcc-CSIC. (Madrid. Spain) \\ $\triangle$ mromero@ietcc.csic.es
}

\begin{abstract}
Porcelain stoneware is a strongly sintered ceramic material fabricated from ball clays-quartzfeldspar mixtures. Porcelain stoneware is characterized by its excellent technical and functional properties (low water absorption, high mechanical properties, resistant to chemical substances and cleaning agents, aesthetic possibilities ...). These characteristic and technical features make that among the different types of ceramic tile, porcelain stoneware is the ceramic product that in the last years has best withstood the economic crisis in the construction sector. These properties are related to the microstructure of porcelain stoneware, which is a grain and bond type with large particles of filler (quartz), mullite crystals, a silica-rich amorphous phase and porosity. The understanding of the relationship between the microstructure and the properties of porcelain stoneware is hardly important for the development and design of these materials whose tendency is the manufacture of thinner tiles with higher dimensions but must continue to comply the specific technical requirements.
\end{abstract}

KEYWORDS: Ceramic; Mechanical properties; Characterization; Microstructure; Pore size distribution

Citation/Citar como: Romero, M.; Pérez, J.M. (2015) Relation between the microstructure and technological properties of porcelain stoneware. A review. Mater. Construcc. 65 [320], e065 http://dx.doi.org/10.3989/mc.2015.05915.

RESUMEN: Relación entre la microestructura y las propiedades tecnológicas en gres porcelánico. Revisión bibliográfica. El gres porcelánico es un material sinterizado fabricado a partir de una mezcla de arcillas, cuarzo y feldespato. Tecnológicamente, el gres porcelánico se caracteriza por sus excelentes características técnicas y funcionales (baja absorción de agua, buenas propiedades mecánicas, resistente a substancias químicas, posibilidades estéticas...). Estas cualidades han propiciado que, entre los diferentes tipos de baldosa cerámica, es el gres porcelánico el producto que mejor ha resistido la crisis económica sufrida por el Sector de la Construcción. Las propiedades tecnológicas están relacionadas con su microestructura, compuesta de partículas de cuarzo, cristales de mullita, fase amorfa y porosidad. El conocimiento de la relación entre la microestructura y las propiedades tecnológicas del gres porcelánico es de gran importancia para avanzar en el diseño y desarrollo de estos materiales, cuya tendencia es la fabricación de piezas de mayor formato y menor espesor pero que deben seguir cumpliendo con los requerimientos especificados para su aplicación.

PALABRAS CLAVE: Cerámica; Propiedades mecánicas; Caracterización; Microestructura; Distribución de tamaño de poro

Copyright: (C) 2015 CSIC. This is an open-access article distributed under the terms of the Creative Commons Attribution-Non Commercial (by-nc) Spain 3.0 License. 


\section{INTRODUCTION}

The change in firing technology in the manufacture of ceramic tiles, from traditional double firing to fast-firing single process, which occurred in the late seventies and early eighties, resulted in significant revolution in the fabrication procedures for wall and floor tiles. Such innovations resulted in a noticeable improvement in the overall technology used in ceramic tile manufacture, particularly as it relates to furnaces and characteristics of the raw materials (1).

After the development of fast-firing, the second great revolution in the ceramic sector was based on the concept of porcelain stoneware, a type of ceramic tile that emerged in the late $70 \mathrm{~s}$ in the district of Saussolo (Italy) $(2,3)$, coinciding with the start of the great technological restructuring in the ceramic sector taken place with the introduction of roller kiln. The appearance of the product in Spain took place a decade later. Specifically, Pamesa started manufacturing in 1988, succeeding Porcelanatto in 1989 and later, already in the 90s, other companies.

Porcelain stoneware tiles are very strongly sintered ceramic materials formed from a finely milled body mixture (4). Ceramic tiles standards (5) use a specific classification and nomenclature that is based on two parameters, i.e. water absorption and forming method. Concerning the shaping method, ceramic tile can be classified in three groups depending if it is moulding by extrusion (A Group), dry pressing (B Group) or by another forming process. In view of its water absorption, ceramic tile can be classified in three groups with well-specified absorption intervals. Table 1 displays the classification of ceramic tiles according to the ISO 13006:2012. Porcelain stoneware tiles are included in the group BIa: Tiles moulded by dry pressing and with water absorption lower than $0.5 \%$.
Regarding the raw material composition, porcelain stoneware paste consists of a mixture of ball clays (sometimes kaolin), quartz and feldspars (6). The clay fraction favours forming operation since it allows plasticity to the green piece and it also provides the sufficient mechanical strength to withstand the stresses before firing. The feldspar fraction develop a liquid phase at low temperatures and assist the sintering process, allowing a virtually zero $(<0.5 \%)$ open porosity and a low level of closed porosity $(<10 \%)$. The quartz promotes thermal and dimensional stability thanks to its high melting point (3, 4, 7-10). Table 2 shows the typical range of composition of commercial porcelain stoneware (11). Besides the main raw materials, energetic fluxing agents and colorants can be added as additives to the paste formulation (12). In recent years, the scientific community is working hard to change the compositions of ceramic pastes for building materials by incorporating industrial and agricultural wastes (13-15). Figure 1 depicts a diagram that represents compositions of triaxial ceramic products in which a standard composition of porcelain tile is located.

From a technological point of view, porcelain stoneware is characterized by excellent technological and functional properties (16-21), such as: low water absorption making it frost resistant and therefore extremely serviceable for outdoor flooring and wall cladding in cold climates; high mechanical properties (hardness, abrasion resistance and bending strength) making it functional for highly trafficked and industrial areas; resistant to chemical substances and cleaning agents, being easy-toclean and thus appropriate for paving areas where hygiene is of prime importance; it can be endowed with a broad spectrum of aesthetic possibilities (body colouring with soluble stains, pressed relief,

TABLE 1. Classification of ceramic tiles with respect to water absorption and shaping (ISO 13006:2012)

\begin{tabular}{|c|c|c|c|c|c|}
\hline & & \multicolumn{4}{|c|}{ Water absorption } \\
\hline & & $\underset{E \leq 3 \%}{\text { Group } I}$ & $\underset{3 \% \leq E<6 \%}{\text { Group }}$ II $_{a}$ & $\underset{6 \% \leq \mathrm{E}<10 \%}{\text { Group } \mathrm{II}_{\mathrm{b}}}$ & $\underset{\mathrm{E}>10 \%}{\text { Group III }}$ \\
\hline \multirow{3}{*}{ Shaping method } & $\underset{\text { Extruded }}{\text { A }}$ & Group AI & $\begin{array}{l}\text { Group } \mathrm{AII}_{\mathrm{a}-1}{ }^{1)} \\
\text { Group } \mathrm{AII}_{\mathrm{a}-2}{ }^{1)}\end{array}$ & 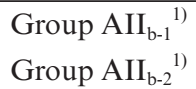 & Group AIII \\
\hline & $\begin{array}{c}\text { B } \\
\text { Dry pressed }\end{array}$ & $\begin{array}{c}\text { Group } \mathrm{BI}_{\mathrm{a}} \\
\mathrm{E} \leq 0.5 \%(\text { annex } \mathrm{G}) \\
{\text { Group } \mathrm{BI}_{\mathrm{b}}}_{0.5 \%<\mathrm{E} \leq 3 \%}\end{array}$ & Group $\mathrm{BII}_{\mathrm{a}}$ & Group $\mathrm{BII}_{\mathrm{b}}$ & Group BIII ${ }^{2}$ \\
\hline & Tiles made by other processes & Group $\mathrm{CI}^{3)}$ & Group $\mathrm{CII}_{\mathrm{a}}^{3)}$ & Group $\mathrm{CII}_{\mathrm{b}}{ }^{3)}$ & Group CIII $^{3)}$ \\
\hline
\end{tabular}

Groups $\mathrm{AII}_{\mathrm{a}}$ and Group $\mathrm{AII}_{\mathrm{b}}$ are divided into two parts (Parts 1 and 2) with different products specifications. Group BIII covers glazed tiles only. There is a low quantity of dry-pressed unglazed tiles produced with E $>10 \%$ that is not covered by this product group.

These tiles are not covered in this International Standard. 
TABle 2. Typical composition range of porcelain stoneware tiles

\begin{tabular}{llc}
\hline & Raw Material & Range (\%) \\
\hline \multirow{3}{*}{ Basic } & Ball clay & $25-55$ \\
& Feldspar & $35-50$ \\
& Feldsphatic sand & $0-20$ \\
Additives & Kaolin & $0-20$ \\
& Fluxing agents & $0-4$ \\
& Colorants & $0-8$
\end{tabular}

polishing, glazing, etc.) (22). Table 3 collects the requirements for porcelain stoneware tiles according the Standard ISO 13006:2012 (5).

All the above characteristic and technical features make that among the different types of ceramic floor and wall tile, porcelain stoneware is the ceramic product that in the last years has best withstood the economic crisis in the construction sector. Figure 2 shows the evolution of the production of porcelain stoneware in Spain during the years 1996-2013. Under the real estate boom that occurred in the period 2002-2013, the production of porcelain tiles grew exponentially, so that the production in 2006 was double that in 2002. However, the poor situation of the global economy and the bursting of the housing bubble led to the fall of the production of ceramic tile in 2007. Nevertheless, considering the overall production of ceramic tile showed in Figure 3, it can be highlighted that porcelain tile is the only ceramic material that has increased its share of production, mainly at the expense of glazed stoneware tile. There is no doubt that this trend is due to a large degree, to the technical features of porcelain stoneware.

The present work aims to give an overview of the relationship between microstructure and technological properties of porcelain stoneware. Once the

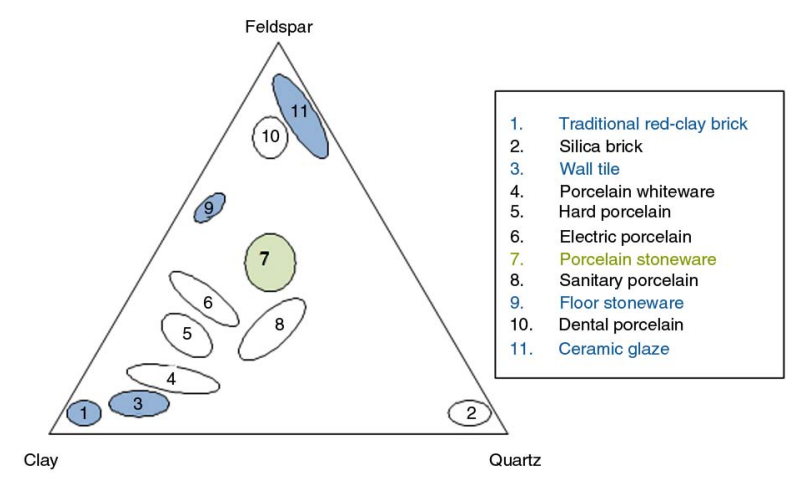

FIGURE 1. Location of different ceramics materials in the feldspar-quartz-clay triaxial diagram. Construction ceramic materials and porcelain stoneware are remarked in blue and green colour respectively. importance of these technological properties has been pointed out, the way to control them is one of the most important objectives of the industry. Therefore, following is detailed the description of the microstructure as a direct consequence of the firing process (porosity) and from the point of view of the main mineralogical composition of tiles (glassy phase, quartz and mullite). Giving the complexity of the process, it has been established that final technological properties of porcelain stoneware tiles are function of several microstructural features. Therefore, it is necessary a precise control of the manufacturing process parameters in order to adjust the technological properties of the fired tiles.

\section{PORCELAIN STONEWARE MICROSTRUCTURE}

Porcelain stoneware tile is fabricated by a faster firing cycle (60-90 min cold-to-cold), in which the tiles are inside the furnace no longer than $90 \mathrm{~min}$ (23). During firing, raw materials react and new crystalline phases are formed $(24,25)$. Kaolinite $\left(\mathrm{Al}_{2} \mathrm{O}_{3} \cdot 2 \mathrm{SiO}_{2} \cdot 2 \mathrm{H}_{2} \mathrm{O}\right)$, illite and mica and feldspar minerals suffer different chemical reactions; as result, part of the quartz in the original raw materials mixture remains in the final composition and mullite $\left(3 \mathrm{Al}_{2} \mathrm{O}_{3} \cdot 2 \mathrm{SiO}_{2}\right)$ develops as an endproduct of the transformation of metakaolinite $\left(\mathrm{Al}_{2} \mathrm{O}_{3} \cdot 2 \mathrm{SiO}_{2}\right)$ originated from the loss of hydroxyl groups in the kaolinitic materials according to the following reactions (26):

$$
\begin{aligned}
& \mathrm{Al}_{2} \mathrm{O}_{3} \cdot 2 \mathrm{SiO}_{2} \cdot 2 \mathrm{H}_{2} \mathrm{O} \stackrel{500^{\circ} \mathrm{C}}{\longrightarrow} \mathrm{Al}_{2} \mathrm{O}_{3} \cdot 2 \mathrm{SiO}_{2} \\
& +2 \mathrm{H}_{2} \mathrm{O} \stackrel{980^{\circ} \mathrm{C}}{\longrightarrow} \mathrm{Si}-\mathrm{Al} \text { spinel }+\mathrm{SiO}_{2} \text { (amorphous) }
\end{aligned}
$$

$\mathrm{Si}-\mathrm{Al}$ spinel $+\mathrm{SiO}_{2}$ (amorphous) $\stackrel{1200^{\circ} \mathrm{C}}{\longrightarrow} 3 \mathrm{Al}_{2} \mathrm{O}_{3} \cdot 2 \mathrm{SiO}_{2}$

$+\mathrm{SiO}_{2}$ (amorphous)

For easy explanation, the phase transformations are expressed as approximate or general chemical reactions. However, the former reactions are not exactly balanced as they are not totally stoechiometric. Moreover, impurities in the starting ceramic paste could result in the development of a liquid phase during firing, which could vary both the temperature of formation and the percentage of the different phases. Consequently, the detailed sequence of the different chemical reactions taking place during firing is complex, as it depends on several factors such as the raw materials composition, ceramic powder characteristics and manufacturing conditions.

The process begins with the formation of metakaolinite $\left(\mathrm{Al}_{2} \mathrm{O}_{3} \cdot 2 \mathrm{SiO}_{2}\right)$ as a result of the loss of kaolinite 
TABle 3. ISO 13006 - Annex G - Group BIa. Dry-pressed ceramic tiles with low water absorption E $\leq 0.5 \%$

\begin{tabular}{|c|c|c|}
\hline Physical properties & Requirements & Test \\
\hline \multicolumn{3}{|l|}{ Water absorption } \\
\hline Percent by mass & Individual maximum $0.6 \%$ & ISO $10545-3$ \\
\hline \multicolumn{3}{|l|}{ Breaking strength, in $\mathbf{N}$} \\
\hline a) Thickness ${ }^{3} 7.5 \mathrm{~mm}$ & Not less than 1300 & \multirow{2}{*}{ ISO $10545-4$} \\
\hline b) Thickness $<7.5 \mathrm{~mm}$ & Not less than 700 & \\
\hline Modulus of rupture, in $\mathrm{N} / \mathrm{mm}^{2}$ & Minimum 35 & \multirow{2}{*}{ ISO 10545-4 } \\
\hline Not applicable to tiles with breaking strength $>3000 \mathrm{~N}$ & Individual minimum 32 & \\
\hline \multicolumn{3}{|l|}{ Abrasion resistance } \\
\hline a) Resistance to deep abrasion of unglazed tiles: removed volume in $\mathrm{mm}^{3}$ & Maximum 175 & ISO $10545-6$ \\
\hline b) Resistance to surface abrasion of glazed tiles intended for use on floors & Report abrasion class and cycles passed & ISO $10545-7$ \\
\hline Crazing resistance & Required & ISO $10545-11$ \\
\hline Glazed tiles & & \\
\hline Frost resistance & Required & ISO $10545-12$ \\
\hline \multicolumn{3}{|l|}{ Resistance to staining } \\
\hline Glazed tiles & Minimum Class 3 & ISO $10545-14$ \\
\hline \multicolumn{3}{|l|}{ Resistance to household chemicals and swimming pool salts } \\
\hline a) Glazed tiles & Minimum GB & \multirow{2}{*}{ ISO $10545-13$} \\
\hline b) Unglazed tiles & Minimum UB & \\
\hline
\end{tabular}

structural water. It is established that the dehydroxylation kinetics is first-order with a dehydroxylation rate directly proportional to the kaolinite surface area $(27,28)$. Moreover, the dehydroxylation of kaolinite is an endothermic process accompanied by a rearrangement of the aluminium ions, which changes from octahedral coordination in kaolinite, to mainly tetrahedral coordination in metakaolinite $(27,28$, 29-31). Subsequently, amorphous silica and spinel is released and at higher temperature they react resulting in mullite formation (32). The amorphous silica liberated in the course of metakaolinite decomposition is highly reactive, possibly assisted by the formation of a

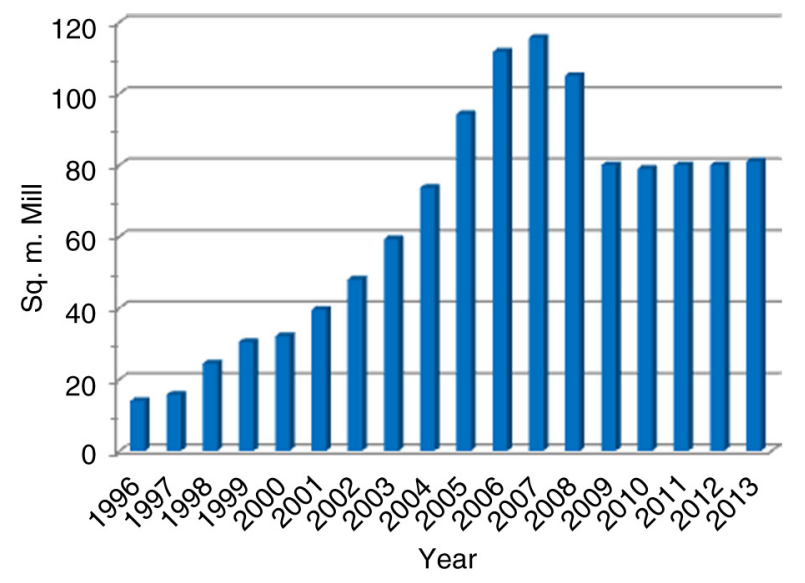

FIGURE 2. Evolution of porcelain stoneware tile production in Spain (source: ASCER). eutectic melt at $990{ }^{\circ} \mathrm{C}$. With regard to the exact structure of the spinel, it is currently under debate (33-35).

Most of the reactions occurring during the firing step of porcelain stoneware are kinetically governed processes. However, the thermal cycles used in industrial production of porcelain tiles are very fast (60-90 min cold-to-cold); so the attainment of thermodynamic equilibrium it unachievable. Therefore, it is frequent that the fired product contains residual feldspar and quartz crystals that have not been completely transformed on firing. Similarly, several authors have reported that only half of the mullite phase that could potentially be generated from raw materials upon firing is formed during the fast-firing

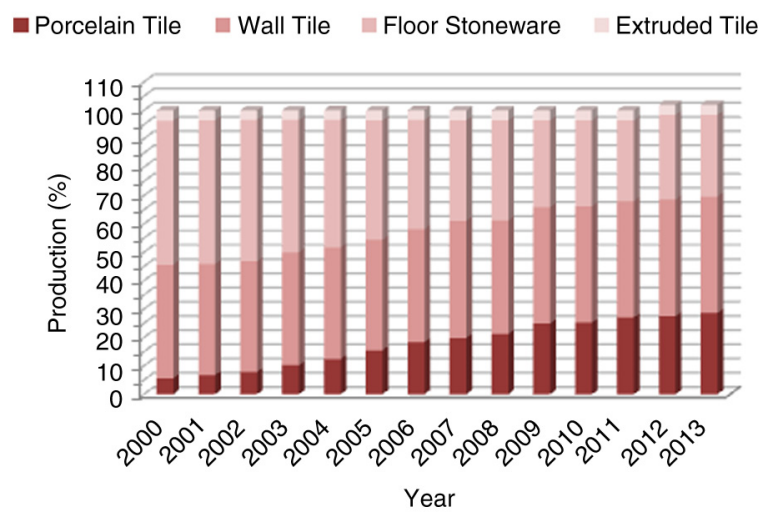

FIGURE 3. Evolution of ceramic tile production in Spain (source: ASCER). 
(a)

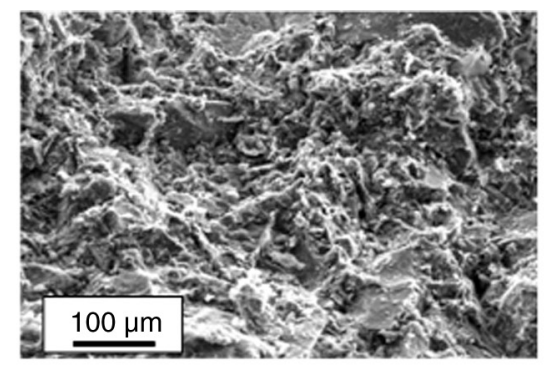

(b)

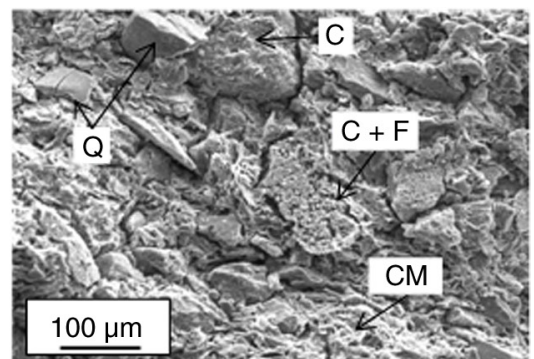

(C)

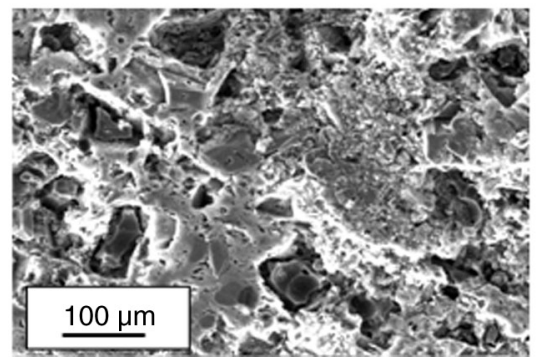

FIGURE 4. Microstructural evolution of porcelain stoneware body on firing. a) Firing $\mathrm{T}^{\mathrm{a}}<1000{ }^{\circ} \mathrm{C}$; b) Firing $\mathrm{T}^{\mathrm{a}}=1000^{\circ} \mathrm{C}, \mathrm{C}=$ clay relict, $\mathrm{C}+\mathrm{F}=$ clay-feldspar relicts, $\mathrm{Q}=$ quartz grains, $\mathrm{CM}=$ ceramic matrix; c) Firing $\mathrm{T}^{\mathrm{a}}>1000^{\circ} \mathrm{C}$.

process $(6,36-38)$. As result, the microstructure of the body is also change during firing. Figure 4 shows the evolution of the microstructure of a porcelain stoneware body during the firing step. Bodies fired below $1000{ }^{\circ} \mathrm{C}$ shows a typical under firing ceramic microstructure with high-interconnected porosity. At $1100{ }^{\circ} \mathrm{C}$, two types of agglomerates are differentiated. Clay relicts that correspond to regions where pure clay was located in the green body and clay-feldspar relicts associated with clay relicts in which feldspar has penetrated. Quartz grains and different agglomerates are surrounded by a ceramic matrix comprised of a mixture of fine grains of quartz, feldspar and kaolinitic clay. Though mullite phase is already forming at this temperature, it is not detectable by SEM due to the small size of the first developed mullite crystals. After firing at above $1200{ }^{\circ} \mathrm{C}$, the microstructure depicts the typical features of a well-fired ceramic body in which all the physical transformations and chemical reactions between the original raw materials have taken place (39). In this state, porcelain stoneware shows a typical grain and bond microstructure with coarse quartz particles held together by a finer matrix consisting of mullite crystals and a glassy phase (40).

Depending on the micro-region from which they develop, mullite crystals have varying shapes and sizes in the fired microstructure. At $\sim 1000^{\circ} \mathrm{C}$, decomposition of pure clay agglomerate relicts lead to fine cuboidal crystals $(<0.5 \mu \mathrm{m})$ termed primary mullite since they form at the lowest temperatures (41-43), whereas those regions in which feldspar particles were well mixed with kaolinitic clay or where feldspar has gone through clay agglomerates form elongated needleshaped crystals termed secondary mullite. Cuboidal or low aspect ratio (1-3:1) primary mullite crystals formed from pure kaolinite clay are surrounded by a highly viscous matrix that inhibits the growth of these crystals and primary mullite shows a low aspect ratio (1-3:1). Mullite crystals derived from feldsparpenetrated clay relicts find a less viscous environment. Their growth is easier, so they achieve a high aspect ratio (3-10:1). Finally, mullite needles formed from areas of mixes of fine clay, feldspar and quartz show a very high aspect ratio $(30-40: 1)$ since they are surrounding by a more fluid liquid enriched in alkalis, which favours the fast growth of crystals. According to Iqbal and Lee notation $(25,44,45)$, these crystals correspond to Type I (low aspect (1-3:1)) primary mullite, Type II (high aspect ratio (3-10:1) secondary mullite and Type III (very high aspect ratio (30-40:1) secondary mullite needles. Figure 5 shows the different mullite crystals morphologies found in porcelain stoneware tiles.

Therefore, the microstructure of a standard porcelain tile consists of quartz grains, primary mullite crystals, secondary mullite crystals, a silica-rich amorphous phase and porosity. The typical mineralogical composition of commercial porcelain stoneware tiles, which commonly is $55 \%-65 \%$ glassy phase, $20 \%-25 \%$ quartz, and $12 \%-16 \%$ mullite (6). On the other hand, porcelain tiles generally exhibit almost $0 \%$ open porosity but they have $2-10 \%$ closed porosity in general.

\section{EFFECT OF MICROSTRUCTURAL FEATURES ON TECHNOLOGICAL PROPERTIES OF PORCELAIN TILES}

\subsection{Porosity}

In any ceramic material, and in particular in wall and floor tiles, porosity has a considerable influence on the technological features, mostly on the 


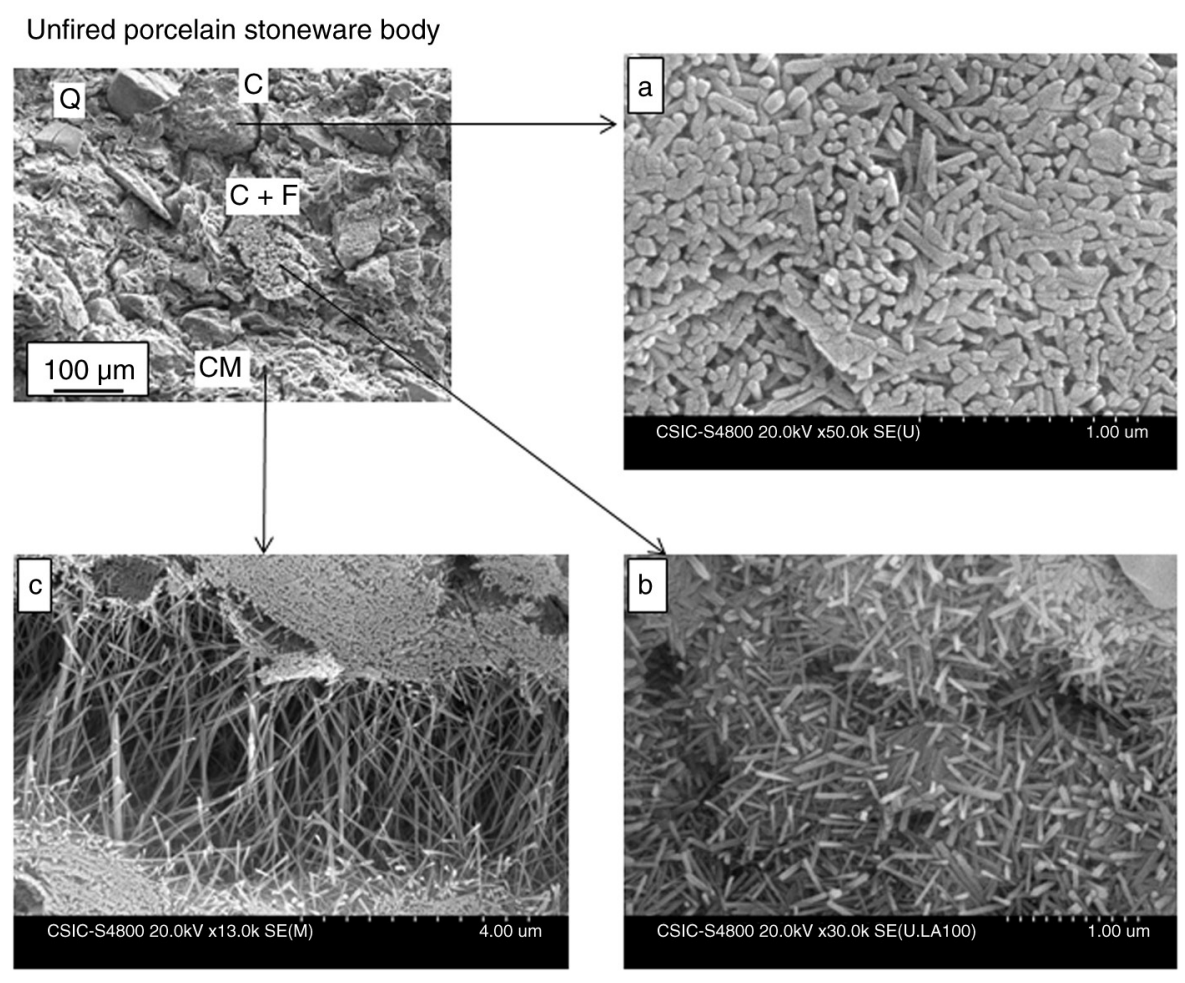

FIGURE 5. Mullite crystal morphology according to the unfired body region from which it develops. a) Type I primary mullite derived from pure clay agglomerate relicts; b) Type II secondary mullite originate from feldspar-penetrated clay relicts;

c) Type III secondary mullite needles developed from areas of mixes of fine clay, feldspar and quartz.

mechanical (modulus of rupture) and surface characteristics (resistance to abrasion, stains and chemical agents). Gil et al. (46) identified the different types of porosity existing in porcelain tiles, in order to associate them with the components of the paste and to analyze the effect of each type of porosity on the physical properties of the fired pieces. Open porosity is composed by intercommunicated irregular channels with a size below $5 \mu \mathrm{m}$ (Figure 6). It is

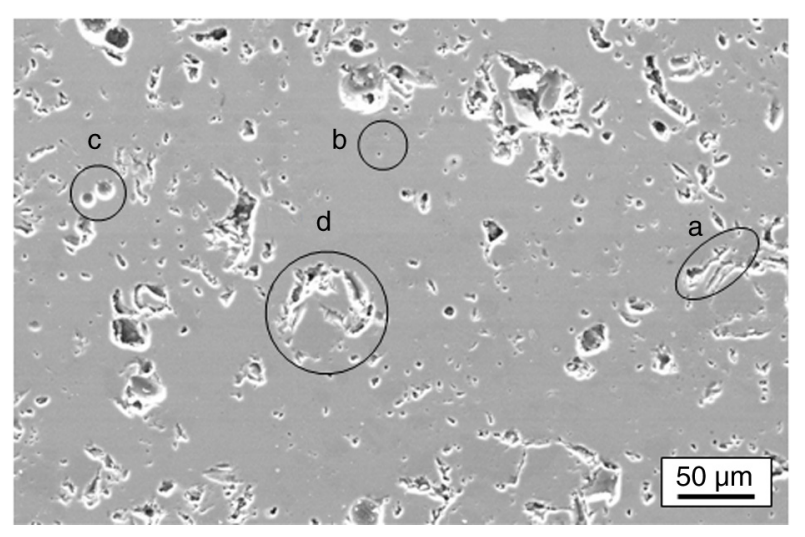

FIGURE 6. Different types of porosity existing in porcelain tiles: open porosity (a); fine closed porosity (b); coarse closed porosity (c); and interparticle porosity (d). formed as results of the loss of volume associated to clay dehydroxylation on firing. During the sintering process, the development of liquid phase is progressively closing the capillaries that constituted the open porosity and fine closed porosity arise, which is comprised by small size closed pores $(<5 \mu \mathrm{m})$ distributed throughout the clayey matrix. Furthermore, larger isolated pores with a spherical shape $(>10 \mu \mathrm{m})$ form the coarse closed porosity. It is directly linked to the melting of the feldspar grains. Finally, interparticle porosity is composed by pores with an irregular morphology located at quartz and feldspar grain boundaries with the glassy matrix. Its origin is due to differences in thermal expansion coefficients of these grains with respect to the glass matrix.

Each of these types of porosity is associated with specific technological properties. Thus, open porosity is responsible for the frost resistance. Coarse closed porosity is associated to the stain resistance because when the fired porcelain stoneware is polished, the closed porosity is exposed at the tile surface. Interparticle porosity is responsible for the reduction in mechanical strength of the fired bodies, since they are considered stress concentrators and facilitate fracture.

With respect to the green compact, the main variables that may interfere in the characteristics of the porous microstructure are particle and grain size 
distribution, morphology, humidity and pressing pressure. Hence, the closed porosity is the result of incomplete densification during sintering and basically depends on the microstructure of the green body and on the firing schedule. Basically, the porous microstructure of the green body is consists of two types of pores: intragranular pores (spaces between the particles that comprise the grains) and intergranular pores (set of voids that are formed during pressing). Another type of pores that can be frequently found inside the larger grains are referred to as "hollow pores" and are characteristics of the spray-drying method used to obtain the ceramic granules $(47,48)$. Based on its characteristics and size, this type of pore can be classified as an intergranular pore. Amorós et al. (49) addressed the effect of green porcelain tile microstructure on the sintering process and on fired product properties. They reported that at the same pressing variables, the larger the composition coarse particle fraction (R3 and $\mathrm{R} 4$ compositions), the less porous (higher bulk density, $\rho_{s}$ ) are the green specimens, which, however, contain larger pores (Figure 7). In contrast, with longer milling (R1 and R2) the resulting specimens are more porous (lower $\rho_{\mathrm{s}}$ ), but the pores are smaller. However, the values of bulk density after firing at $1175{ }^{\circ} \mathrm{C}$ indicated that the pore size growth during sintering depends on pore size in the green body, so that fired product porosity will depend more on pore size than on pore volume of the green body. The authors concluded that the presence of large pores in the green body hinders the sintering process, and requires a higher firing temperature to reach maximum product densification. Moreover, the minimum attainable porosity is higher and the size of the remaining pores increases.

Alves et al. (50-52) conducted different investigations to correlate the porous microstructure of the green compact with the closed porosity and stain resistance of the fired product. They pointed out that the granulometric distribution of the spray-dried

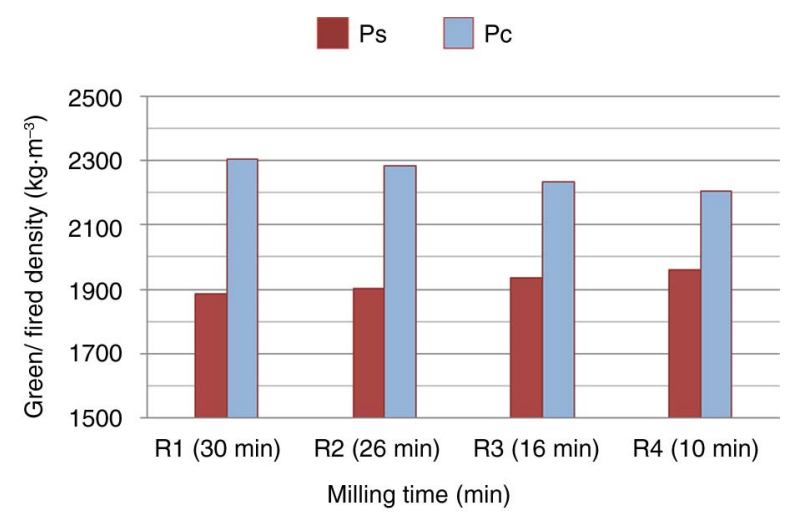

FIGURE 7. Effect of milling time on bulk density of green bodies $\left(\rho_{s}\right)$ and specimens fired at $1175^{\circ} \mathrm{C}\left(\rho_{c}\right)$

(Figure drawn from data reported in (49)). mixture does not interfere significantly in the pore size distribution of the fired material. The only effect cause by the use of granules with distinct characteristics was on the area of surface pores. In this case, the area occupied by surface pores is directly related to the intensity of the stains, i.e., the larger the area the more visible the stain.

Gualtieri et al. (53) reported a strong dependence between the total porosity and the glass content in the fired body. They remarked that a liquid phase contents higher than about $66 \%$ does not result in a more sintered body. The authors attributed this finding to the presence of gas bubbles entrapped in the liquid phase which cannot be eliminated by viscous sintering, thus forming closed pores which contribute to total porosity. As pores are eliminated during sintering through liquid phase sintering, the most important raw material responsible for the amount, nature and characteristics of the liquid phase during sintering, and consequently the ability of a composition to eliminate pores in the green compact, should be feldspar. Alves et al. (54) studied the correlations between the particle size distribution of feldspar, the characteristics of the pores in the green compact, the elimination of these pores during sintering, and the susceptibility to staining of sintered polished surfaces. They concluded that slight variations in the average particle size of feldspar can lead to significant changes in the porous microstructure of the final product, thereby modifying its stain resistance. Thus, higher feldspar particle size increases favours the formation of denser granules during the granulation stage. Although densification degree of the green compact is higher in these conditions, the use of particles with larger diameters causes the volume and diameter of closed pores to increase due to the lower reactivity attained during sintering.

Likely, the negative effect of porosity on technological properties of porcelain stoneware is related to stain resistance in polished tiles. Porcelain tiles frequently undergo a polishing process, aimed to reduce their surface roughness and increase their gloss (52). During polishing, the removal of a fine surface layer, which normally varies from 0.5 to $1.5 \mathrm{~mm}$ depending of the tile characteristics (specially curvature and decoration process), reveals a new surface composed of numerous open pores that were previously "closed" inside the material $(18,55,56)$. Hence, Tucci et al. $(57,58)$ and Dondi et al. $(59,60)$ correlated the stain resistance with the bulk and surface characteristics of porcelain stoneware tiles, providing a predictive model based on the surface roughness and on the number size and morphology of the pores. As a result of fast-firing cycles used in their production, porcelain tiles retain a significant amount of residual porosity, which is heterogeneously distributed through the thickness of the tile. In order to evaluate the dependence of porosity with depth, 
a porcelain tile can be considered as a material with functional gradient and therefore it may be modeled as a multilayered system, which consists of a ceramic matrix and residual pores. The determination of the pores volume fraction as a function of the distance from the tile surface and the application of different simulation models revealed a spatial variation of the elastic properties, which cannot be identified by traditional experimental methods such as bending tests and resonance techniques (61).

Some works suggest that the staining is dependent on the diameter of pores on the polished surface of porcelain tiles. Thus, pores responsible for the staining of porcelain surface are in the 5-20 $\mu \mathrm{m}(62,63)$. Indeed, large pores $(>30 \mu \mathrm{m})$ facilitates the removal of staining agents by the cleaning processes. In contrast, the penetration of the staining agent is hindered in very small pores $(<5 \mu \mathrm{m})(64)$. Alves et al. (65) carried out a study to ascertain if the thickness of the layer removed by polishing can modify the superficial porous microstructure and stain resistance of the final surface of porcelain stoneware tile. The thickness of the layer removed by polishing may affect the intensity of the stains, since pore size distribution and morphology change from the surface toward the centre of the ceramic body. In fact, the area occupied by the pores did not vary significantly with the increasing the layer thickness removed by polishing. However, as the wear advanced into the sample, there was a decrease in the occurrence of pores with critical stain diameters, i.e., between 5 and $20 \mu \mathrm{m}$ (Figure 8). On the other hand, increasing pore size in the cross section of the tiles as the distance from the original surface increased was also observed. This increase in pore size apparently was accompanied by an increment in the area occupied by the pores, indicating the existence of porosity gradient along the cross section. As result, the lower the thickness of the layer removed by polishing the higher the intensity of visible stains. The authors indicated that the removal of a $1.5 \mathrm{~mm}$ layer from the surface by polishing contributed more to reduce the intensity of stains than a thinner layer.

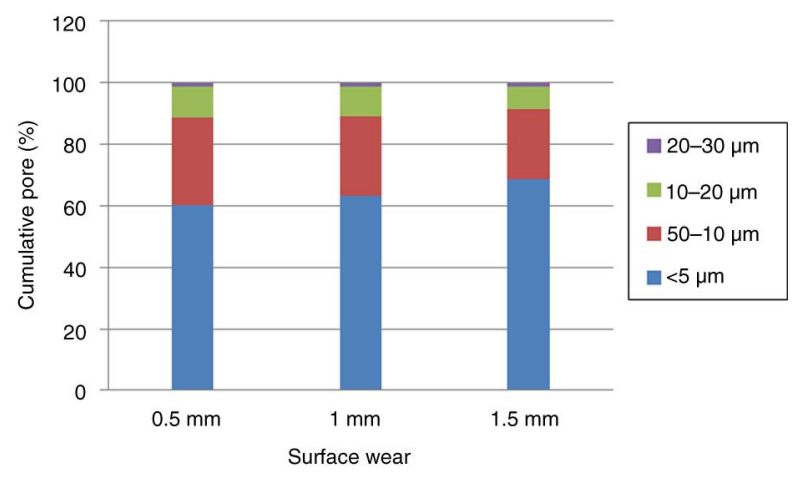

FIGURE 8. Distribution of surface pore diameters of porcelain stoneware tile after progressive wear (Figure drawn from data reported in (65)).
Other parameters affecting porosity in fired porcelain stoneware are moulding pressure and thickness of the green body. Pérez et al. $(66,67)$ addressed that open porosity generally decreases as moulding pressure increases; this reduction is more noticeable at lower thicknesses. Higher moulding pressure leads to highly compact unfired bodies with a lower volume of voids; therefore, the elimination of open pores by the liquid phase formed during firing is favoured. As the thickness and moulding pressure increase, the number of closed pores decreases (Figure 9). The authors also reported on a strong relationship between the numbers of closed pores and the tile thickness; the number of pores increased with the thickness of the tile. This result is most likely due to the temperature gradient inside the tile during the firing cycle. This gradient is expected to increase as the thickness increases, which leads to differences in the liquid phase viscosity from the surface to the core of the tiles. Thus, as the thickness increases, the viscosity in the core of the tile will increase, which inhibits the removal of voids. Therefore, the fired product exhibits a greater number of pores (Figure 10a). Regarding the moulding pressure, the number of pores was observed to increase at higher pressure, which was
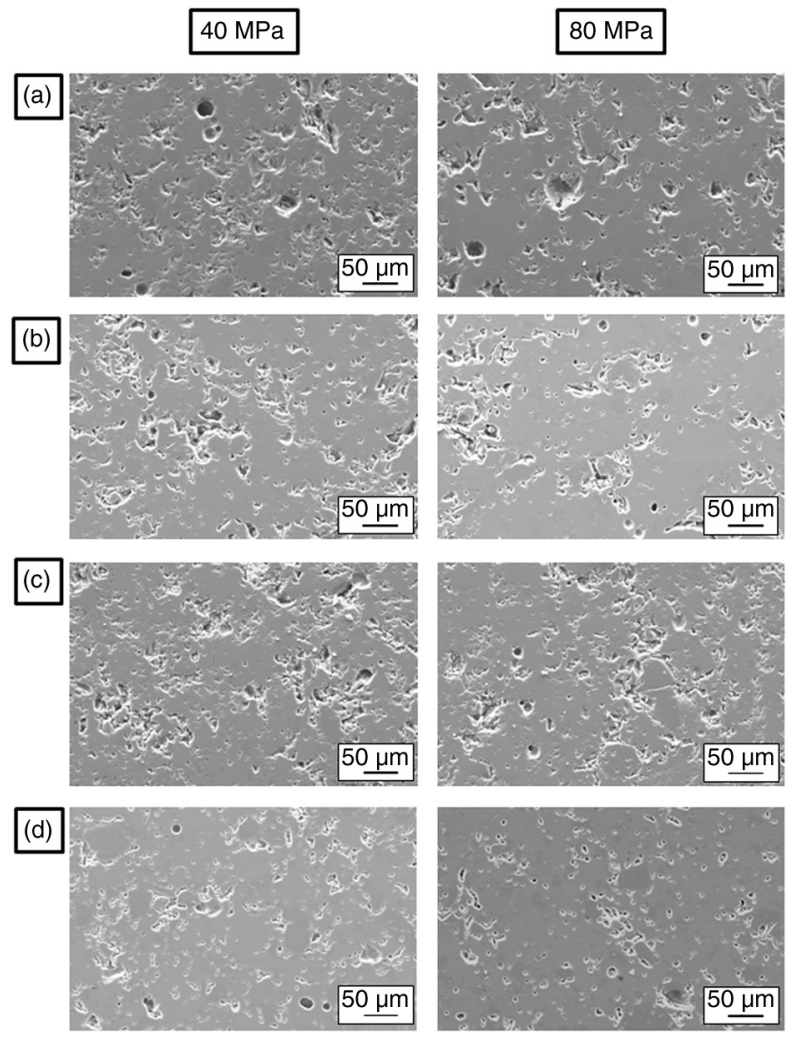

FIGURE 9. Internal microstructure of fired porcelain stoneware that is shaped at two moulding pressures $(40$ and $80 \mathrm{MPa})$ and four thicknesses $(3,4.5,6$ and $9 \mathrm{~mm})(67)$ (reprinted with permission from Elsevier). 
(a)

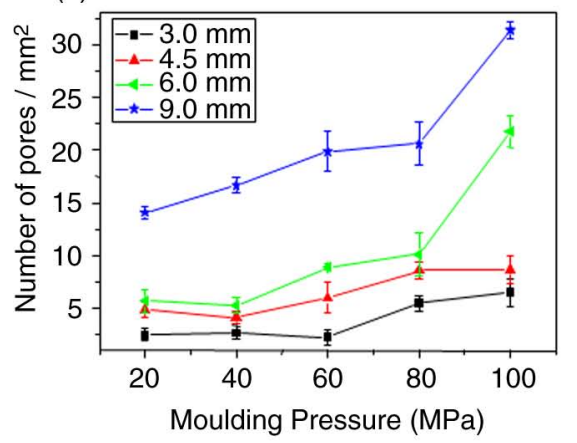

(b)

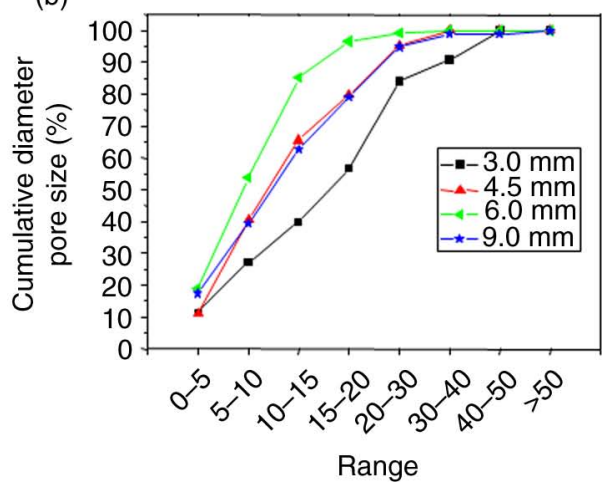

FIGURE 10. a) Pores density and b) cumulative diameter of pore size as a function of the thicknesses of the fired bodies (Fig. 10b corresponds to porcelain tiles shaped at $20 \mathrm{MPa}$ ) (67) (reprinted with permission from Elsevier).

more significant for the thickest tiles (6 and $9 \mathrm{~mm}$ ). The greater contact in particles in the unfired tiles shaped at higher pressures locks the microstructure and inhibits the rearrangement of particles at the first stage of sintering. Concerning the size of pore, it is related to tile thickness. Therefore, the thinnest tiles contain a significant percentage of large-sized pores, whereas the thickest tiles contain a significant proportion of smaller-sized pores (Figure 10b).

The elastic modulus (E) of a porous material is closely related to both the amount of porosity and one or more aspects of the pore character. The elastic modulus of porcelain stoneware depends on the shape and distribution of the porosity, which is considered as a second phase with $\mathrm{E}=0$, and in general, E decreases as the total porosity increases (68). Generally, bending strength (BS) in ceramics decreases exponentially by increasing porosity, and the denser the fired bodies are the higher the BS is (69-71). But it is not only dependent on the percentage of porosity but also on the size and shape of the pores. Thus, it is known that interconnecting pores act as large fracture flaws reducing bending strength; conversely spherical, uniformly distributed pore with a size in the range 5-20 $\mu \mathrm{m}$ have a positive effect on bending strength $(69,72,73)$.

\subsection{Glassy phase nature}

The densification of porcelain stoneware occurs throughout a viscous phase sintering, with the development of a liquid phase that flows, by capillary pressure, in the interconnected holes between the particles $(46,47)$, and leads to the development of a ceramic bonding, constituted by a glassy matrix embedding new-crystalline phases and part of the residual crystals (74). Thus, the viscosity of the liquid phase will affect the sintering process and as a result, the microstructure of fired products.

The dynamic evolution of both microstructure and phase composition during firing makes it difficult to predict the behaviour of porcelain stoneware with classical models (based on viscosity and surface tension of the liquid phase) (75). Esposito et al. (74) evaluated the possibility to use nephelinesyenite, as fluxing agent, in a body mix used for porcelain stoneware tile. Compared to pure feldspars, nepheline-syenite contains higher percentage of alkaline oxides, $\mathrm{K}_{2} \mathrm{O}+\mathrm{Na}_{2} \mathrm{O}$ is about $9-12 \%$ in feldspars, whereas it is larger than $14 \%$, in nephelinesyenite. Starting from a reference mix composition (48.6 wt. \% of clay, $15.6 \mathrm{wt} . \%$ of potassium feldspathic sand and $35.5 \mathrm{wt} . \%$ of sodium feldspathic sand), different amounts (5.0, 10.0 and $15.6 \mathrm{wt} . \%)$ of sodium feldspar were replaced with the same amounts of nepheline-syenite. The authors pointed out that the presence of the nepheline-syenite in the standard body mix strongly favours the sintering behaviour. Adding nepheline-syenite decreases the viscosity of the glassy phase, which in turn causes an increase in the shrinkage rate and improves the sintering process. Consequently, the time necessary to obtain a water absorption value $<0.5 \%$ is greatly reduced. The maximum value of shrinkage in the samples containing nepheline is higher than the maximum value in the standard composition, and furthermore, it is reached in shorter times. The reference sample reaches a open porosity $\sim 0 \%$ (water absorption $<0.5 \%$ ) after $100 \mathrm{~min}$ of soaking time, while for the modified composition only 25-30 min of soaking time are enough to obtain well sintered samples (Figure 11). The fired modified compositions show homogeneous microstructures, characterised by smaller pores, with a narrow pore size distribution, compared with the standard sample. Moreover, the mechanical characteristics as Vickers hardness, flexural strength and Weibull's modulus, increase for the modified compositions. All that is correlated with a better microstructural homogeneity and lower amount of glassy phase. The use of a $5 \%$ of nepheline-syenite allows reaching the best results. However, the range of dimensional 


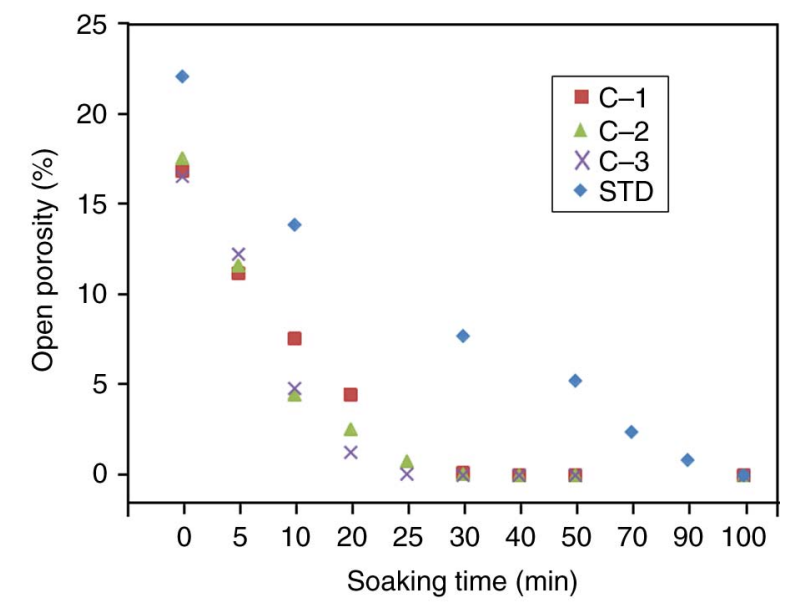

FIGURE 11. Open porosity soaking time of porcelain stoneware compositions fired at $1260^{\circ} \mathrm{C}(\mathrm{STD}=$ reference mix composition; $\mathrm{Cl}=5 \mathrm{wt} . \%$ of potassium feldspathic sand were replaced with nepheline-syenite; $\mathrm{C} 2=10 \mathrm{wt} . \%$ of potassium feldspathic sand were replaced with nepheline-syenite; $\mathrm{C} 3=15.6$ wt. $\%$ of potassium feldspathic sand were replaced with nephelinesyenite) (Figure drawn from data reported in (74)).

stability drastically reduces, and a negative shrinkage is observed (expansion) when higher amounts of nepheline-syenite are added.

Suvaci et al. (76) studied the effect of composition on viscosity of porcelain stoneware tiles and the role of the viscosity on microstructure development and stain resistance. The authors stated that the viscosity of the amorphous phase is directly related to $\mathrm{Na}_{2} \mathrm{O} / \mathrm{K}_{2} \mathrm{O}$ ratio (Figure 12). As the ratio increases, the viscosity decreases due to smaller dimensions of the sodium with respect to potassium ions. Therefore, changing compositions of the porcelain stoneware tiles results in viscosity change of the system which is expected to influence the sintering and microstructure development. In this sense, densification rate can be related to reduction in viscosity according to the following equation (77) [1]:

$$
\frac{d \rho}{d t}=\frac{k n^{1 / 3} \gamma^{1 / 3}}{\eta}
$$

where $k$ and $n$ are constants, $\gamma$ is surface energy and $\eta$ is viscosity. Surface energy does not change significantly with the compositional changes. As a result, viscosity remains as a key parameter to affect densification. Accordingly, while too high viscosity is not desired due to very slow densification kinetics, too low viscosity may also bring some additional problems such as pyroplastic deformation.

The viscosity also has an effect on closed porosity in both the degree of porosity and the aspect ratio of the pores. Decreasing viscosity does not only result in less closed porosity but also favours spherical pore morphology, which is critical for getting porcelain stoneware tiles with high stain resistance (76). Although lower the viscosity results in less and spherical closed porosity with improved stain resistance, too low viscosity can bring additional problems such as pyroplastic deformation of the tiles, which is a factor to consider in the formulation of the ceramic body. Accordingly, two critical viscosity values have been noticed; (i) the upper viscosity limit above which insufficient densification occurs and/or irregular pore structure is observed and (ii) the lower viscosity limit below which the tiles exhibit pyroplastic deformation.

Pyroplastic deformation is the bending of a ceramic specimen caused by gravity during heat treatment. This property is especially important when firing products with very low porosity like porcelain tiles, due their content in melting materials. Piroplasticity is related to an excess of liquid phases formed during firing or to a reduced viscosity of these phases. It depends on different parameters

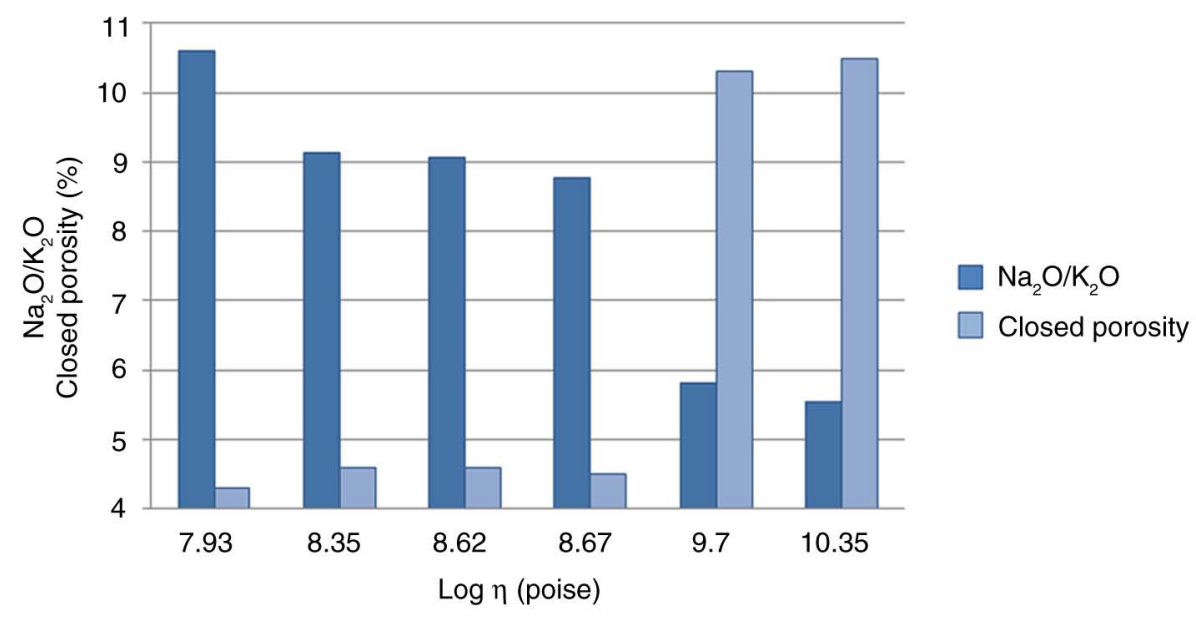

FIGURE 12. Effect of the $\mathrm{Na}_{2} \mathrm{O} / \mathrm{K}_{2} \mathrm{O}$ ratio on viscosity of the porcelain stoneware and on closed porosity of porcelain stoneware fired at $1220^{\circ} \mathrm{C}$ (Figure drawn from data reported in (76)). 
such as the firing zone temperature; the heating rate and the time in which the specimens remain at the maximum temperature (60), but also on the composition in raw materials of the porcelain body. Bernardin et al. (78) used a statistical design to study the influence of different minerals on the pyroplasticity of porcelain tile pastes. They reported that the strongest influence was caused by the presence of sodium oxide in ceramic compositions, which is related to the decrease in the viscosity of the formed liquid phase in the ceramic system and the increase of the observed pyroplastic deformation. Aydin et al. (79) reported similar findings when studied the influence of lithium oxide, as auxiliary flux, on the pyroplastic deformation of triaxial porcelain bodies. The partial substitution (up to $4 \mathrm{wt} . \%$ ) of spodumene for in a standard body resulted in decreased pyroplastic deformation index, which was attributed to the fact that the addition of spodumene led to further dissolution of quartz and thus increased the viscosity of glassy phase.

Regarding the effect of glassy phase content in on mechanical properties of porcelain stoneware tiles, there are controversial results. Several studies suggest a close relationship between the amount of glassy phase present in the fired body and bending strength or fracture toughness (80). In contrast, other studies have claimed that an increase in the vitreous phase decreases the mechanical resistance of porcelain bodies (81). Discordant results may be to the fact that the amount of liquid phase in porcelain stoneware is related to the close porosity of the sample but also to the thermal tensile stresses developed at the surface during fast cooling.

Zanelli et al. (75) studied a full representative sample of commercial porcelain stoneware tiles. They highlighted that some important aspects of porcelain stoneware sintering, deeply involving the non-crystalline component, are still not fully understood, in particular: the stability of mullite during the formation of viscous melt, as it affects the chemical composition of the glassy phase; the role of microstructure, as there are evidences that the matrix of porcelain stoneware body, which include glassy phase and micro-crystals, is the real viscous phase governing the densification kinetics; and the onset of viscous flow, as there are no detailed study concerning the transformation from the formation of viscous melt to the densification stage.

\subsection{Quartz}

Quartz is a basic component in porcelain stoneware composition as it promotes thermal and dimensional stability because of its high melting point. During firing, quartz grains tend to dissolve in the liquid phase at high temperature so that it is estimated that a $64-85 \%$ of the quartz in the starting composition remained undissolved in the fired tile.
Concerning the function of quartz in the strength of a porcelain body, the mismatch in the thermal expansion coefficient, $\alpha$, between quartz particles $\left(\alpha \approx 15-26 \times 10^{-6}{ }^{\circ} \mathrm{C}^{-1}\right)$ and the silicate glass matrix $\left(\alpha \approx 5-8 \times 10^{-6}{ }^{\circ} \mathrm{C}^{-1}\right)$ generate a compressive stress on the matrix, which leads to strength reinforcement in the porcelain bodies (82). According to this theory, the quartz particles have a decisive contribution on increasing the fracture energy, either by increasing the state of compressive residual stress in the glass matrix, or by promoting a combination of the mechanisms of crack deflection and microcracking. Typically this mechanism is visible as crack branching at the impact of the crack with a quartz grain. When the crack propagates through a feldspar grain, it does not deviate from its path but when it meets a stressed quartz grain, the energy is dissipated and propagation stopped (9).

Sánchez et al. (83) conducted a comparative study on the mechanical properties of a wide range of polished porcelain stoneware tiles produced by several companies from different countries. The investigation concluded that the mechanical properties of porcelain tiles are mostly defined by the quartz content in the fired pieces, as quartz acts as reinforcement phase, increasing the toughness of the material and thus its mechanical strength. De Noni et al. (84) achieved similar results with respect to the role of quartz. They noted that the mechanical strength of porcelain stoneware increases with the proportion of quartz, confirming the role of reinforcement of quartz particles dispersed in the matrix. As a result of the rapid cooling rate in industrial firing cycles and the large quantity of glassy phase $(50-65 \%)$ developed on firing, porcelain tile may develop a macroscopic residual stress profile resembling that typically found in glass tempering processes $(85,86)$. During rapid cooling, thermal tensile stresses develop at the porcelain stoneware tile surface. So that residual stress increases as the material cools more rapidly in the temperature range in which the tempering process occurs. Since the stress is compressive, an increase in thermal stresses is associated to an increase in mechanical strength. De Noni et al. (87) analysed how the cooling stage of the firing cycle influences porcelain tile microstructure and mechanical behaviour. They pointed out that apparent toughness increased in proportion to the residual stress increase, so the tempering in porcelain tile can be considered a toughening mechanism.

However, the positive effect of quartz on the mechanical properties of porcelain stoneware is not always revealed, and even different researches has highlighted opposite results. Thus, Cavalcante et al. (17) highlighted that strong tensile stresses, in the order of 330-370 MPa, are developed around quartz particles, leading to a structural weakening and presumably a particle debonding from the matrix. 
The negative effect of quartz on the mechanical properties of porcelain stoneware is also revealed by Hutchings et al. (88). They stated that adding quartz and/or increasing quartz particle size in the porcelain tile starting composition raised the porosity of the fired specimens significantly. Moreover, there was a strong increase in tile specific wear rate with increasing quartz. This factor, together with the resulting deterioration in surface quality, suggested that in order to improve polishing efficiency and enhance polished surface quality, both quartz content and quartz particle size should be minimized in porcelain stoneware compositions.

As indicated above, the mechanical strength for rapidly cooled porcelain stoneware tiles increases due to the development of compressive macroscopic residual stress at the surface of the pieces. However, this increase is lower than is to be expected on the basis of the measured residual stresses (89). After the allotropic transformation of quartz $\left(573{ }^{\circ} \mathrm{C}\right)$, the particles undergo pronounced shrinkage, which increases microscopic stresses. As the piece cools, the particles begin to debond from the matrix, giving rise to peripheral cracks. As the cooling is rapid, thermal tensile stresses form at the surface; peripheral cracks thus encounter more favourable growth conditions, which lead to an increase in natural flaw size. This microstructural damage adversely affects the product's mechanical behaviour. Different studies have shown that the debonding degree depends on the quartz particle size $(90,91)$, so that particles larger than $\sim 50 \mu \mathrm{m}$ would completely debond from the matrix (complete cracking around particles) but particles sized between $\sim 5-50 \mu \mathrm{m}$ would be partly detached from the matrix (partial peripheral cracks around particles) (Figure 13). Therefore, the mechanical strength of porcelain stoneware strongly depends on quartz particle size and the increasing particle size leads to an increase of mechanical strength.

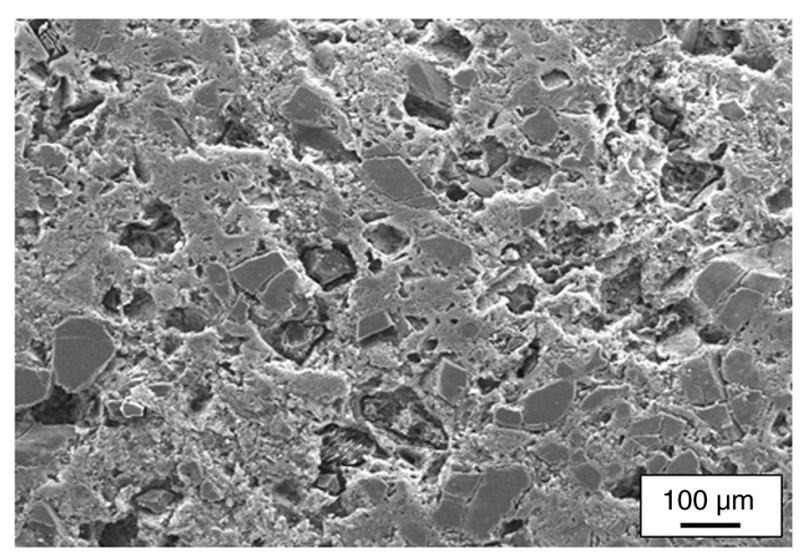

FIGURE 13. SEM image of porcelain stoneware showing cracking and debonding of quartz grains associated with the particle size.

\subsection{Mullite}

Several theories on mechanical properties of porcelain bodies assume that strength can be attributed to mullite content and morphology. The mullite hypothesis for the strength of porcelain stoneware tiles establishes that the feltlike interlocking of fine mullite needles are responsible for the strength and consequently bending strength increases when the percentage of mullite crystals developed in the tile increases. This assumption was first proposed in porcelains by Zoellner (92) and subsequently supported by different authors. Thus, Calcavante et al. (17) studied the behaviour of polished porcelain stoneware tiles, focusing the attention on a better understanding of the complex relationships among microstructural, mechanical, tribological and functional characteristics. They pointed out that mullite crystals tend to increase the mechanical performances, through a predominant mechanism of matrix reinforcement. Mullite undergoes compressive stresses during cooling that, consequently, promote a material strengthening. Actually, when a crack front passes through a compressive stressed region, its propagation is contrasted if no additional external forces are applied. Similar findings were reported by Carbajal et al. (93) after studying the evolution of the crystalline phases of the two porcelain stoneware compositions prepared with different contents of glass formers and its influence on the mechanical reinforcement. More recently, De Noni et al. (94) highlighted that the hypothesis of interconnection of mullite crystals as a mechanism for strengthening triaxial porcelain stoneware is clearly observed only when the pieces are fast cooled.

However, at times, the beneficial effect of mullite content is not evident. Several researchers have not found a clear relationship between mullite content and bending strength $(72,73,74)$. De Noni et al. (84) in a study on the influence of composition on mechanical behaviour of porcelain tile showed that mullite significantly worsen the fracture energy, which invalidates the mullite hypothesis as a mechanism to strengthen the porcelain tile.

Thus, the effect of mullite content on mechanical strength is also controversial. Martín-Márquez et al. (95) studied the evolution of mechanical properties on firing in porcelain stoneware in an attempt to establish the influence of the microstructure, taking into consideration percentage, shape and size of mullite crystals. The authors revealed the bending strength is directly associated to the aspect ratio shown by secondary mullite needles (Figure 14). An increase in the aspect ratio of crystals was observed to increase the bending strength, which reaches maximum values when Type III secondary mullite needles join together and give rise to clusters or packs of needles (Figure 15).

Similar findings on the effect of the aspect ratio of mullite needles on the mechanical strength of 


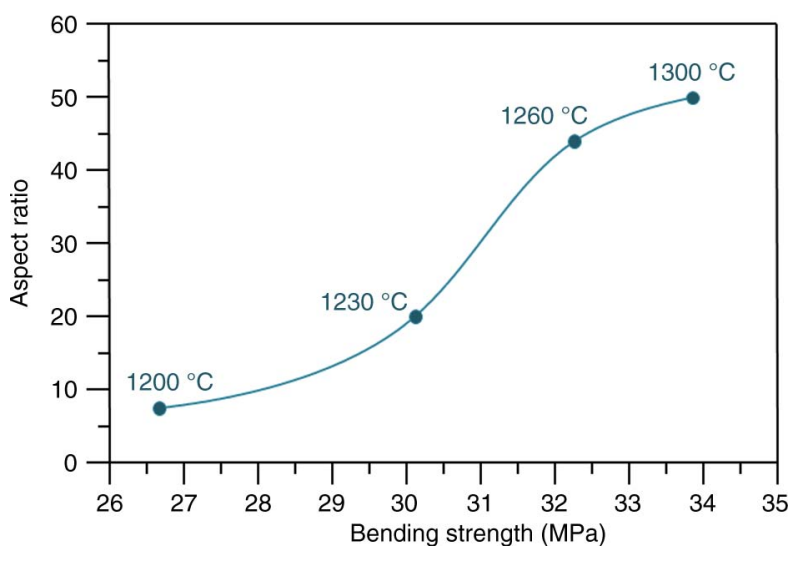

FIGURE 14. Variation of bending strength in porcelain stoneware as a function of the aspect ratio shown by secondary mullite needles developed at different firing temperatures (95) (reprinted with permission from Elsevier).
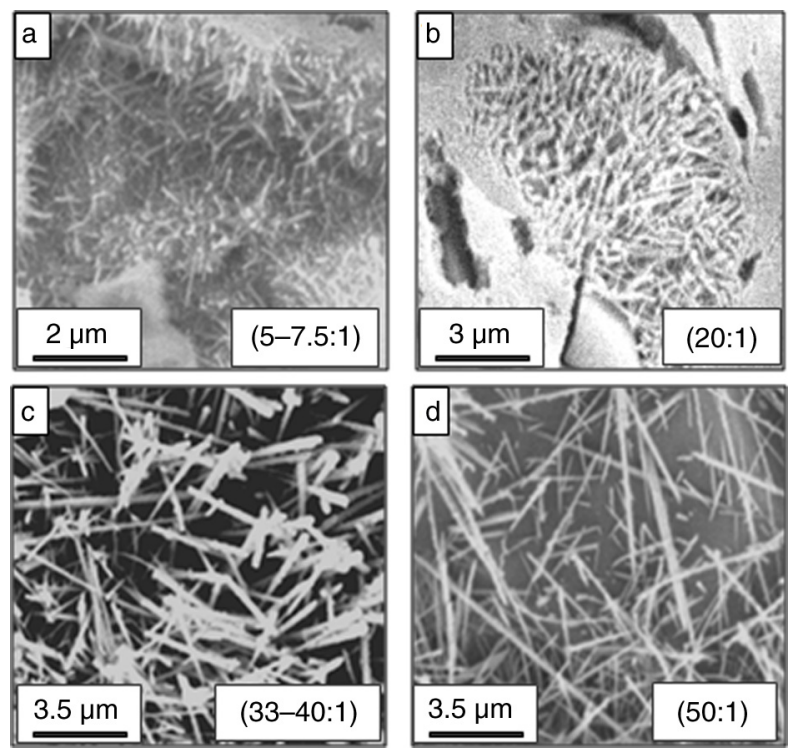

FIGURE 15. SEM images of freshly fractured etched porcelain stoneware pellets fast fired at different temperatures (a) $1200^{\circ} \mathrm{C}$, (b) $1250^{\circ} \mathrm{C}$, (c) $1260^{\circ} \mathrm{C}$ and (d) $1300{ }^{\circ} \mathrm{C}$ (95) (reprinted with permission from Elsevier).

porcelain stoneware were reported by Pérez et al. $(66,67)$. The authors studied the influence of thickness and moulding pressure on the technological properties and microstructure of porcelain stoneware tiles. The microstructural study was focused on the morphology of mullite crystals. They reported that the morphology of secondary mullite was affected by moulding pressure so that it varied from Type II at low pressure to Type III at higher pressures. The secondary Type III mullite fibres joined together and give rise to cluster or pack of needles. As result, the bending strength improves when the aspect ratio increased, from 29:1 in samples pressured at $20 \mathrm{MPa}$ to $62: 1$ in samples pressured at $100 \mathrm{MPa}$ (Figure 16).

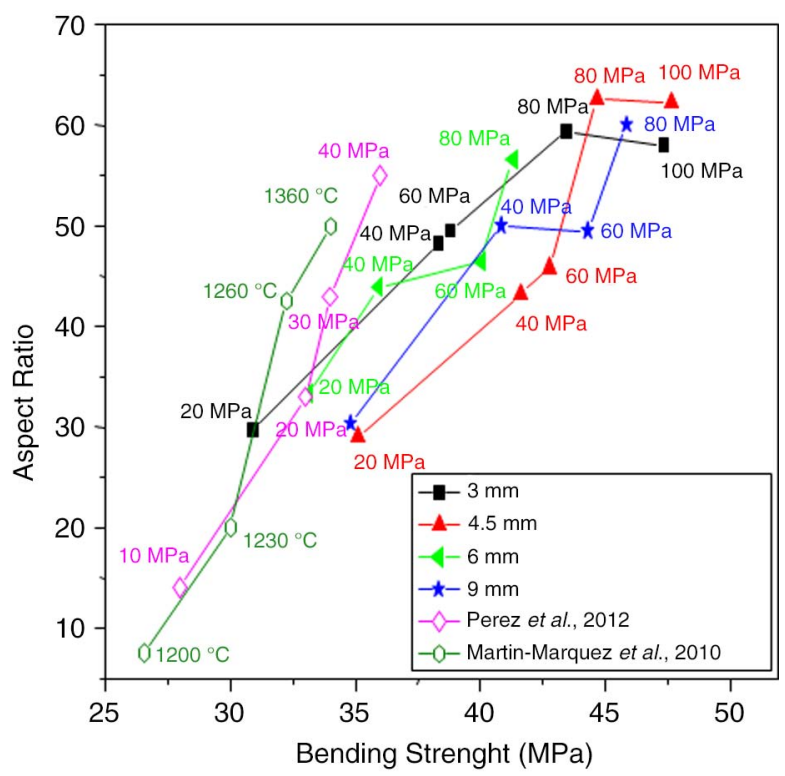

FIGURE 16. Variation in bending strength as a function of the aspect ratio of the secondary mullite needles in porcelain stoneware pieces moulded with different thickness and at variable pressures (67) (reprinted with permission from Elsevier).

Concerning the effect of mullite crystals on the elastic modulus and wear resistance, in general these properties increase for higher mullite content, which can be explained by the highest value of Young's modulus (mullite $=210 \mathrm{GPa}$, quartz $=78 \mathrm{GPa}$, glass $=70 \mathrm{GPa}$ ) and expansion coefficient for mullite comparing to other components (96).

\section{FINAL REMARKS}

Considering the overall production of ceramic tile and the poor situation of the global economy, it must be highlighted that porcelain tile is the only ceramic material that has increased its share of production. There is no doubt that this trend is due to the technical features of porcelain stoneware, which are related to its microstructure consisting of quartz grains, mullite crystals, a silica-rich amorphous phase and porosity.

The technical characteristics of porcelain stoneware are closely associated to the porous texture of the fired product. The main effect of porosity is related to stain resistance, which is dependent on the diameter of pores. Bending strength and elastic modulus are not only dependent on the percentage of porosity but also on the size and shape of the pores. Uniformly distributed pores with a size in the range 5-20 $\mu \mathrm{m}$ have a positive effect on bending strength.

The effect of glassy phase and quartz content on mechanical properties of porcelain stoneware is controversial. Several studies suggest a close relationship between the amount of glassy phase or residual quartz 
present in the fired body and bending strength or fracture toughness. In contrast, other studies have claimed that an increase in the vitreous phase decreases the mechanical resistance of porcelain bodies.

The effect of mullite content on mechanical strength of porcelain stoneware is also open to discussion. The mullite hypothesis for the strength of porcelain tiles establishes that the feltlike interlocking of fine mullite needles is responsible for the porcelain strength and consequently bending strength increases when the percentage of mullite increases. However, sometimes the beneficial influence of mullite content on bending strength is not evident. What does seem clear is that mechanical strength of porcelain stoneware is directly related to the aspect ratio of secondary mullite needles since an increase in the aspect ratio of crystals was observed to increase the bending strength. Finally, the elastic modulus of porcelain stoneware increases for higher mullite content due to the highest value of Young's modulus for mullite comparing to other components.

Over the manuscript it has been pointed out that there are some major questions regarding the final properties of porcelain stoneware that ought to be clarified and, in the author's opinion will rise up a new way of approaching the relationship between microstructure and technical properties.

\section{REFERENCES}

1. Barbieri, L.; Bonfatti, L.; Ferrari, A.M; Leonelli, C.; Manfredini, T.; Settembre Blundo, D. (1995) Relationship between microstructure and mechanical properties in fully vitrified stoneware. In: Ceramics: Charting the Future, Techna. Srl., Modena, 99-105.

2. Sánchez, E. (2002) Technical considerations on porcelain tile products and their manufacturing process. In: VII World Congress on Ceramic Tile Quality, vol. I, Cámara Oficial de Comercio, Industria y Navegación, Castellón, 57-84.

3. Sánchez, E.; García-Ten, J.; Sanz, V.; Moreno, A. (2010) Porcelain tile: Almost 30 years of steady scientifictechnological evolution. Ceram. Int. 36 [3], 831-845. http:// dx.doi.org/10.1016/j.ceramint.2009.11.016

4. Manfredini, T.; Pellacani, G.C.; Romagnoli, M.; Pennisi, L. (1995) Porcelainized stoneware tiles. Am. Ceram. Soc. Bull. 74 [5], 76-79.

5. ISO 13006:2012. Ceramic tiles: Definitions, classification, characteristics and marking.

6. Dondi, M.; Ercolani, G.; Melandri, C.; Mingazzini, C.; Marsigli, M. (1995) The chemical composition of porcelain stoneware tiles and its influence on microstructural and mechanical properties. Interceram 48, 75-83

7. Barba, A.; Beltrán, V.; Feliu, C.; García, J.; Gines, F.; Sánchez, E.; Sanz, V. (2002) Materias primas para la fabricación de soportes de baldosas cerámicas, 2 ed., Instituto de Tecnología Cerámica, Castellón.

8. Sánchez, E.; Orts, M.J.; Ten, J.G.; Cantavella, V. (2001) Porcelain tile composition effect on phase formation and end products. Am. Ceram. Soc. Bull. 80 [6], 43-49.

9. Leonelli, C.; Bondioli, F.; Veronesi, P.; Romagnoli, M.; Manfredini, M.; Pellacani, G.C.; Cannillo, V. (2001) Enhancing the mechanical properties of porcelain stoneware tiles: a microstructural approach. J. Eur. Ceram. Soc. 21 [6], 785-793. http://dx.doi.org/10.1016/S0955-2219(00)00266-1.

10. Biffi, G. (1997) Il gres porcellanato: Manuale di fabricacione e tecniche di impego, Faenza editrice, Faenza.

11. Llorens, F.G. (2000) Materias primas para la fabricación de gres porcelánico. Ceram. Inf. 286, 908-913.
12. Llorens, F.G. (1999) Materias primas fundentes para la fabricación de gres porcelánico. Ceram. Inf. 254, 21-26.

13. Galán-Arboledas, R.J.; Merino, A.; Bueno S. (2013) Use of new raw materials and industrial wastes to improve the possibilities of using ceramic materials from Bailén (Jaén, southern Spain). Mater. Construcc. 63 [312], 553-568. http:// dx.doi.org/10.3989/mc.2012.03412.

14. Xavier, G.C.; Savoya, F.; Maja, P.C.; Alexandre, J. (2012) Durability of fired clay bricks containing granite power. Mater. Construcc. 62 [306], 213-229. http://dx.doi.org/ 10.3989/mc.2012.60710.

15. Martinez, M.L.; Eliche, D; Cruz, N.; Corpas, F.A. (2012) Utilization of bagasse from the beer industry in clay brick production for building. Mater. Construcc. 62 [306], 199-212. http://dx.doi.org/10.3989/mc.2012.63410.

16. Dondi, M.; Fabbri, B.; Manfredini, T.; Pellacani, G.C. (1995) Microstructure and mechanical properties of porcelainized stoneware tiles. In: Proceedings of the 4th ECerS, Fanenza Editrice, Faenza, 319-326.

17. Tenorio Cavalcante, P.M.;Dondi, M.; Ercolani, G.; Guarini, G.; Melandri, M.; Raimondo, M.; Rocha e Almendra, E. (2004) The influence of microstructure on the performance of white porcelain stoneware. Ceram. Int. 30 [6], 953-963. http://dx.doi.org/10.1016/j.ceramint.2003.11.002.

18. Sánchez, E.; Ibáñez, M.J.; García-Ten, J.; Quereda, M.F.; Hutchings, I.M.; Xu, Y.M. (2006) Porcelain tile microstructure: implications for polished tile properties. J. Eur. Ceram. Soc. 26 [13], 2533-2540. http://dx.doi.org/10.1016/j. jeurceramsoc.2005.06.002.

19. Brusa. A. (1987) Características, prestaciones y tecnología de producción de pavimento gresificado, no esmaltado, con efecto granito (gres porcelánico). Tec. Ceram. 159, 562-57.

20. Brusa, A.; Contoli L.; Dardi, M. (1994) Gres porcelánico fino. Ceram. Inf. 204, 17-26.

21. Manfredini, T.; Romagnoli, M.; Rincón, J. Ma. (1996) Porcelanized stoneware:architectural, processing and physicomechanical properties. Mater. Construcc. 46 [242-243], 107-118. http://dx.doi.org/10.3989/mc.1996.v46.i242-243.533.

22. Mucci, L. (1990) Topicality and prospects of increasing the aesthetic value of porcelain stoneware. Ceramurgia 20 [1], 20-23.

23. Martín-Márquez, J.; Rincón, J. Ma.; Romero, M. (2008) Effect of firing temperature on sintering of porcelain stoneware tiles. Ceram. Int. 34 [8], 1867-1873. http://dx.doi. org/10.1016/j.ceramint.2007.06.006.

24. Martín-Márquez, J.; De la Torre, A.G.; Aranda, M.A.G.; Rincón, J. Ma.; Romero, M. (2009) Evolution with Temperature of Crystalline and Amorphous Phases in Porcelain Stoneware. J. Am. Ceram. Soc. 92 [1], 229-234. http://dx.doi.org/10.1111/j.1551-2916.2008.02862.x.

25. Iqbal, Y.; Lee, E.J. (2000) Microstructural evolution in triaxial porcelain. J. Am. Ceram. Soc. 83 [12], 3121-27. http:// dx.doi.org/10.1111/j.1151-2916.2000.tb01692.x.

26. Chakravorty, A.K.; Ghosh, D.K. (1991) Kaolinite mullite reaction-series-the development, significance of a binary aluminosilicate phase. J. Am. Ceram. Soc. 74 [6], 1401-1406. http://dx.doi.org/10.1111/j.1151-2916.1991.tb04119.x.

27. Brindley, G.W: Nakahira, M. (1957) Kinetics of dehydroxylation of kaolinite and halloysite. J. Am. Ceram. Soc. 40 [10], 346-350. http://dx.doi.org/10.1111/j.1151-2916.1957. tb12549.x.

28. Johnson, H.B.; Kessler, F. (1969) Kaolinite dehydroxilation kinetics. J. Am. Ceram. Soc. 52 [4], 199-204. http://dx.doi. org/10.1111/j.1151-2916.1969.tb13365.x.

29. Brindley, G.W; Nakahira, M. (1959) The kaolinite-mullite reaction series: I, a survey of outstanding problems. J. Am. Ceram. Soc. 42 [7], 311-314. http://dx.doi.org/10.1111/ j.1151-2916.1959.tb14314.x.

30. Brindley, G.W.; Nakahira, M. (1959). The kaolinite-mullite reaction series: II, metacaolín. J. Am. Ceram. Soc. 42 [7], 314-318. http://dx.doi.org/10.1111/j.1151-2916.1959. tb14315.x.

31. Schneider, H.; Okada, K.; Pask, J. (1994) Mullite and mullite ceramics, Wiley, New York.

32. Bowen, N.L.; Greig, J.W. (1924) The system: $\mathrm{Al}_{2} \mathrm{O}_{3}-\mathrm{SiO}_{2}$. J. Am. Ceram. Soc. 7 [4], 238-254. http://dx.doi.org/10.1111/ j.1151-2916.1924.tb18190.x. 
33. Brindley, G.W.; Nakahira, M. (1959) The kaolinite-mullite reaction series: III, the high-temperature phases. J. Am. Ceram. Soc. 42 [7], 319-323. http://dx.doi.org/10.1111/j.11512916.1959.tb14316.x.

34. Okada, K.; Otsuka, N.; Osaka, J. (1986) Characterization of spinel phase formed in the kaolin-mullite termal sequence. J. Am. Ceram. Soc. 69 [10], c251-c253. http:// dx.doi.org/10.1111/j.1151-2916.1986.tb07353.x

35. Sonuparlak, B.; Sarikaya, M.; Aksay I.A. (1987) Spinel phase formation during $980^{\circ} \mathrm{C}$ exothermic reaction in the kaolinite-to-mullite reaction series. J. Am. Ceram. Soc. 70 [11], 837-842. http://dx.doi.org/10.1111/j.1151-2916.1987. tb05637.x

36. Gislimberti, A.; Maschio, R.D.; Campolo, M.P.; Primio, S. (1998) Porcelain Stoneware. Correlation between ChemicalPhysical Properties of the Raw Materials and Technological Characteristics of the Final Product: Durability and Mechanical Strength. Ceram. Acta, 9, 46-47.

37. Sánchez, E.; García, J.; Barba, A.; Feliú C. (1998) Effect of Porcelain Tile Raw Materials Composition on Pressing Behaviour of the Resulting Spray Dried Powder. Ceram. Acta 9, 44 45.

38. Sánchez, E.; Orts, M.J.; García, J.; de Lamus, R. (1998) Effect of Porcelain Tile Raw Materials Compositions on the Arising Phases in Firing. Ceram. Acta 9, 205-7.

39. Martín-Márquez, J.; Rincón, J. Ma.; Romero, M. (2010) Mullite development on firing in porcelain stoneware bodies. J. Eur. Ceram. Soc. 30 [7], 1599-1607. http://dx.doi. org/10.1016/j.jeurceramsoc.2010.01.002.

40. Lee, W.E.; Rainforth, W.M. (1994) Ceramic Microstructures. Chapman and Hall, London, U.K

41. Norton, C.L. (1931) The Influence of Time on Maturing Temperature of Whiteware Bodies II. J. Am. Ceram. Soc. 14 [3], 192-206. http://dx.doi.org/10.1111/j.1151-2916.1931. tb16931.x

42. McConville, C.J.; Lee, E.W.; Sharp, J.H. (1998) Microstructural evolution in fired kaolinite. Br. Ceram. Trans. 97 [4], 162-168.

43. Chen, C.Y.; Lan, G.S.; Tuan, W.H. (2000) Microstructural evolution of mullite during the sintering of kaolin powder compacts. Ceram. Int. 26 [7], 715-720. http://dx.doi. org/10.1016/S0272-8842(00)00009-2

44. Iqbal, Y.; Lee, E.W. (1999) Fired Porcelain Microstructures Revisited. J. Am. Ceram. Soc. 82 [12], 3584-90. http:// dx.doi.org/10.1111/j.1151-2916.1999.tb02282.x

45. Lee, W.E.; Iqbal, Y. (2001) Influence of mixing on mullite formation in porcelain. J. Eur. Ceram. Soc. 21 [14], 2583-2586. http://dx.doi.org/10.1016/S0955-2219(01)00274-6.

46. Gil, C.; Peiró, M.C.; Gómez, J.J.; Chiva, L.; Cerisuelo, E. Carda, J.B. (2006) Estudio de la porosidad en soportes del gres porcelánico. Ceram. Inf. 336, 53-56.

47. Beltrán, V.; Ferrer, C.; Bagán, V.; Sánchez, E.; Garcia, J.; Mestre, S. (1996) Influence of pressing powder characteristics and sintering temperature on the porous microstructure and stain resistance of porcelain tile. In: IV World Congress on Ceramic Tile Quality, Cámara Oficial de Comercio, Industria y Navegación, Castellón, 133-48.

48. Amorós, J.L.; Cantavella, V.; Jarque, J.C.; Felíu, C. (2008) Fracture properties of spray-dried powder compacts: effect of granule size. J. Eur. Ceram. Soc. 28 [15], 2823-34. http://dx.doi.org/10.1016/j.jeurceramsoc.2008.05.004.

49. Amoros, J.L.; Orts, M.J.; Garcia-Ten, J.; Gozalbo, A.; Sánchez, E. (2007) Effect of the green porous texture on porcelain tile properties. J. Eur. Ceram. Soc. 27 [5], 2295-2301. http://dx.doi.org/10.1016/j.jeurceramsoc.2006.07.005.

50. Alves, H.J.; Melchiades, F.G.; Boschi, A.O. (2010) Effect of spray-dried powder granulometry on the porous microstructure of polished porcelain tile. J. Eur. Ceram. Soc. 30 [6], 1259-1265. http://dx.doi.org/10.1016/j.jeurceramsoc. 2009.11.018.

51. Alves, H.J.; Melchiades, F.G.; Boschi, A.O. (2010) Spraydried powder granulometry: Influence on the porous microstructure of polished porcelain tile. Bol. Soc. Esp. Ceram. V. 49 [4], 239-246.

52. Alves, H.J.; Minussi, F.B.; Melchiades, F.G.; Boschi, A.O. (2011) Characteristics of pores responsible for staining of polished porcelain tile. Ind. Ceram. 31 [1], 21-26.
53. Gualtieri, M.L.; Romagnoli, M.; Gualtieri, A.F. (2011) Influence of body composition on the technological properties and mineralogy of stoneware: A DOE and mineralogical-microstructural study. J. Eur. Ceram. Soc. 31 [5], 673-685. http://dx.doi.org/10.1016/j.jeurceramsoc.2010.12.002.

54. Alves, H.J.; Melchiades, F.G.; Boschi, A.O. (2012) Effect of feldspar particle size on the porous microstructure and stain resistance of polished porcelain tiles. J. Eur. Ceram. Soc. 32 [10], 2095-2102. http://dx.doi.org/10.1016/j. jeurceramsoc.2012.03.019

55. Hutchings, I.M.; Xu, Y.; Sánchez, E.; Ibáñez, M.J.; Quereda, M.F. (2006) Porcelain tile microstructure: implications for polishability. J. Eur. Ceram. Soc. 26 [6], 1035-1042. http:// dx.doi.org/10.1016/j.jeurceramsoc.2004.12.019.

56. Jazayeri, S.H.; Salem, A.; Timellini, G.; Rastelli, E. (2007) A kinetic study on the development of porosity in porcelain stoneware tile sintering. Bol. Soc. Esp. Ceram. V. 46 [1], 1-6.

57. Tucci, A.; Esposito, L.; Malmusi, L.; Piccinini, A. (2002) Wear resistance and stain resistance of porcelain stoneware tiles. Key Eng. Mater. 206, 1759-1762.

58. Esposito, L.; Tucci, A.; Rastelli, E.; Palmonari, C.; Selli, S. (2002) Stain resistance of porcelain stoneware tile. Am. Ceram. Soc. Bul. 81 [10], 38-42.

59. Dondi, M.; Guarini, G.; Raimondo, M.; Almendra, E.R.; Cavalcante, P.M.T. (2004) Stain resistance of porcelain stoneware tiles: The influence of microstructure. Key Eng. Mater. 264-268, 1511-1514.

60. Dondi, M.; Ercolani, G.; Guarini, G.; Melandri, C.; Raimondo, M.; Almendra, E.R.E.; Cavalcante, P.M.T. (2005) The role of surface microstructure on the resistance to stains of porcelain stoneware tiles. J. Eur. Ceram. Soc. 25 [4], 357-365. http://dx.doi.org/10.1016/j. jeurceramsoc.2004.01.017

61. Cannillo, V.; Esposito, L.; Rambaldi, E.; Sola, A.; Tucci, A. (2009) Effect of porosity on the elastic properties of porcelainized stoneware tiles by a multi-layered model. Ceram. Int. 35 [1], 205-211. http://dx.doi.org/10.1016/j. ceramint.2007.10.015.

62. Alves, H.J.; Minussi, F.B.; Melchiades, F.G.; Boschi, A.O. (2009) Porosidade susceptível ao manchamento em porcelanato polido. Ceram. Ind. 14 [1], 21-6.

63. Rastelli, E.; Tucci, A.; Esposito, L.; Selli, S. (2002) Stain resistance of porcelain stoneware tile: mechanisms of penetration of staining agents and quantitative evaluation. Ceram. Acta 14 [1], 30-7.

64. Dondi, M.; Raimondo, M.; Zanelli, C. (2008) Stain resistance of ceramic tiles. Ceram. World Rev. 77, 82-9.

65. Alves, H.J.; Freitas, M.R.; Melchiades, F.G.; Boschi, A.O. (2011) Dependence of surface porosity on the polishing depth of porcelain stoneware tiles. J. Eur. Ceram. Soc. 31 [5], 665-671. http://dx.doi.org/10.1016/j.jeurceramsoc.2010.11.028.

66. Pérez, J.M.; Rincón, J. Ma.; Romero, M. (2012) Effect of moulding pressure on microstructure and technological properties of porcelain stoneware. Ceram. Int. 38 [1], 317-325. http://dx.doi.org/10.1016/j.ceramint.2011.07.009.

67. Pérez, J.M.; Romero, M. (2014) Microstructure and technological properties of porcelain stoneware tiles moulded at different pressures and thicknesses. Ceram. Int. 40 [1], 1365-1377. http://dx.doi.org/10.1016/j.ceramint.2013.07.018.

68. Aduda, B.O.; Nyongesa, F.W. (2000) Role of aspect ratio in elastic modulus-porosity relationship of triaxial porcelain. Br. Ceram. Trans. 99 [5], 206-211. http://dx.doi. org/10.1179/096797800680956.

69. Kobayashi, Y.; Ohira, O.; Kato, E. (1992) Effect of firing temperature on bending strength of porcelains for tableware. J. Am. Ceram. Soc. 75 [7], 1801-1806. http://dx.doi. org/10.1111/j.1151-2916.1992.tb07200.x.

70. Hamano, K.; Hirayama, M. (1994) Effect of quartz addition on mechanical strength of porcelain bodies prepared from pottery stone. J. Ceram. Soc. Jap. Int. Ed. 102 [7], 664-668.

71. Dinsdale, A. and Wilkinson, W.T. (1966) Strength of Whiteware bodies. Proc. Br. Ceram. Trans. 6, 119-136.

72. Ece, O.I.; Nakagawa, Z. (2002) Bending strength of porcelains. Ceram. Int. 28 [2], 131-140. http://dx.doi.org/ $10.1016 / \mathrm{S} 0272-8842(01) 00068-2$. 
73. Stathis, G.; Ekonomakou, A.; Stournaras, C.J.; Ftikos, C. (2004) Effect of firing conditions, filler grain size and quartz content on bending strength and physical properties of sanitaryware porcelain. J. Eur. Ceram. Soc. 24 [8], 2357-2366. http://dx.doi.org/10.1016/j.jeurceramsoc.2003.07.003.

74. Esposito, L.; Salem, A.; Tucci, A.; Gualtieri, A.; Jazayeri, S.H. (2005) The use of nepheline-syenite in a body mix for porcelain stoneware tiles. Ceram. Int. 31 [2], 233-40. http:// dx.doi.org/10.1016/j.ceramint.2004.05.006.

75. Zanelli, C.; Raimondo, M.; Guarini, G.; Dondi, M. (2011) The vitreous phase of porcelain stoneware: Composition and evolution during sintering and physical properties J. Non-Cryst. Solids 357 [16-17], 3251-3260. http://dx.doi. org/10.1016/j.jnoncrysol.2011.05.020.

76. Survaci, E.; Tamsu, N. (2010) The role of viscosity on microstructure development and stain resistance in porcelain stoneware tiles. J. Eur. Ceram. Soc. 30 [15], 3071-3077. http://dx.doi.org/10.1016/j.jeurceramsoc.2010.06.010.

77. Rahaman, M.N. (2003) Ceramic processing and sintering. $2^{\text {nd }}$ Edition, Marcel-Dekker Inc., New York.

78. Bernardin, A.M.; Souza de Medeiros, D.; Riella, H.G. (2006) Pyroplasticity in porcelain tiles. Mat Sci Eng A-Struct 427 [1-2], 316-319. http://dx.doi.org/10.1016/j. msea.2006.04.073.

79. Aydin, T.; Kara, A. (2014) Effect of spodumene addition on pyroplastic deformation of porcelain stoneware. $J$. Ceram. Process. Res. 15 [6], 486-491.

80. Correia, S.L.; Oliveira, A.P.N.; Hotza, D.; Segadaes, A.M. (2006) Properties of Triaxial Porcelain Bodies: Interpretation of Statistical Modeling. J. Am. Ceram. Soc. 89[11], 3356-3365. http://dx.doi.org/10.1111/j.1551-2916.2006.01245.x.

81. Amigó, J.M.; Clausell, J.V.; Esteve, V.; Delgado, J.M.; Reventós, M.M. Ochando, L.E.; Debaerdemaeker, T; Martí, F. (2004) X-ray powder diffraction phase analysis and thermomechanical properties of silica and alumina porcelains. J. Eur. Ceram. Soc. 24 [1], 75-81. http://dx.doi. org/10.1016/S0955-2219(03)00119-5.

82. Ohya, Y.; Takahashi, Y. (1999) Acoustic emission from a porcelain body during cooling. J. Am. Ceram. Soc. 82 [2], 445-448. http://dx.doi.org/10.1111/j.1551-2916.1999. tb20083.x

83. Sánchez, E.; García-Ten, J.; Ibáñez, M.J.; Feliu, C.; Sánchez, J.; Portolés, J. (2004) Estudio comparativo de propiedades de piezas de gres porcelánico pulido. Ceram. Inf. 314, 56-66.

84. De Noni Jr., A.; Hotza, D.; Cantavella, V.; Sánchez, E. (2010) Influence of composition on mechanical behaviour of porcelain tile. Part II: Mechanical properties and microscopic residual stress. Mat Sci Eng A-Struct 527 [7-8], 1736-1743. http://dx.doi.org/10.1016/j.msea.2009.10.060.

85. McMaster, R.A. (1989) Fundamentals of tempered glass. Ceram. Eng. Sci. Proc. 10, 193-206.

86. Navarro, J.M. (2003) El Vidrio. Constitución, Fabricación y Propiedades. $3^{\mathrm{a}}$ edición, CSIC, Madrid.

87. De Noni Jr., A.; Hotza, D.; Cantavella, V.; Sanchez, E. (2008) Influence of macroscopic residual stresses on the mechanical behavior and microstructure of porcelain tile. J. Eur. Ceram. Soc. 28 [13], 2463-2469. http://dx.doi. org/10.1016/j.jeurceramsoc.2008.03.003.

88. Hutchings, I.M.; Xu, Y.; Sánchez, E.; Ibáñez, M.J.; Quereda, M.F. (2006) Porcelain tile microstructure: implications for polishability. J. Eur. Ceram. Soc. 26 [6], 1035-1042. http:// dx.doi.org/10.1016/j.jeurceramsoc.2004.12.019.

89. De Noni Jr. A. Hotza, D. Cantavella, V; Sanchez, E. (2009) Effect of quartz particle size on the mechanical behaviour of porcelain tile subjected to different cooling rates. J. Eur. Ceram. Soc. 29 [6], 1039-1046. http://dx.doi. org/10.1016/j.jeurceramsoc.2008.07.052.

90. Senapati, U.; Carty, W.M. (1998) Porcelain-raw materials, processing, phase evolution, and mechanical behavior. J. Am. Ceram. Soc. 81 [1], 3-20. http://dx.doi.org/10.1111/ j.1151-2916.1998.tb02290.x.

91. Warshaw, S.I.; Seider, R.J. (1967) Comparison of strength of triaxial porcelains containing alumina and silica. J. Am. Ceram. Soc. 50 [7], 337-342. http://dx.doi.org/10.1111/ j.1151-2916.1967.tb15128.x.

92. Zoellner, A. (1908) Some chemical and physical properties of porcelain. Sprechsall 41, 471-473.

93. Carbajal, L.; Rubio-Marcos, F.; Bengochea, M.A.; Fernández, J.F. (2007) Properties related phase evolution in porcelain ceramics. J. Eur. Ceram. Soc. 27 [13-15], 4065-4069. http://dx.doi.org/10.1016/J.jeurceramsoc.2007.02.096.

94. De Noni Jr, A.; Hotza, D.; Cantavella, V.; Sánchez, E. (2011) Influence of composition on mechanical behaviour of porcelain tile. Part III: Effect of the cooling rate of the firing cycle, Mat Sci Eng A-Struct 528 [9], 3330-3336. http://dx.doi.org/10.1016/j.msea.2010.12.086.

95. Martín-Márquez, J.; Rincón, J. Ma.; Romero, M. (2010) Effect of microstructure on mechanical properties of porcelain stoneware. J. Eur. Ceram. Soc. 30 [15], 3063-3069. http://dx.doi.org/10.1016/j.jeurceramsoc.2010.07.015.

96. Dondi, M.; Guarini, G.; Melandri, C.; Raimondo, M.; Cavalante, P.M.T.; Zanelli, C. (2005) Resistance to deep abrasion of porcelain stoneware tiles: Key factors. Ind. Ceram. 25 [2], 71-78. 